\title{
RECENZJE
}

PRZEGLLD SEJMOWY

nr 3(158)/2020, s. 275-285; https://doi.org/10.31268/PS.2020.45

\author{
Bogusław Banaszak
}

\section{Regulacja wyboru sędziów Trybunału Konstytucyjnego w ustawie z dnia 25 czerwea 2015 r. o TK i jej implikacje}

Wydawnictwo Sejmowe, Warszawa 2018, s. 179

Trwający od połowy 2015 r. do końca 2016 r. spór wokół Trybunału Konstytucyjnego rozgrywał się na trzech płaszczyznach. Po pierwsze, chodziło o stwierdzenie niemożności wyboru sędziów na zapas, co ustanowił art. 137 ustawy o TK z 25 czerwca 2015 r.; po wtóre o spluralizowanie składu Trybunału Konstytucyjnego i wreszcie po trzecie - o próbę wypracowania przez Prawo i Sprawiedliwość nowego modelu funkcjonowania sądu konstytucyjnego. Najważniejsza wydawała się ta trzecia sprawa pozostająca ciągle przedmiotem sporu ustrojowego znacznie wykraczającego poza wydarzenia z lat 2015-2016, która nie znalazła jednak, jak dotychczas, zadowalającego rozwiązania. Kwestię wyboru sędziów wyjaśniły natomiast dwa orzeczenia Trybunału Konstytucyjnego: wyrok z 3 grudnia 2015 r. (K 34/15) oraz postanowienie z 7 stycznia 2016 (U 8/15). Efektem postanowienia TK było w gruncie rzeczy pozostawienie Sejmowi carte blanche w sprawie wyborów sędziów w dniu 8 października 2015 r.

SŁowa KLuCzowe: Trybunał Konstytucyjny, wybór sędziów konstytucyjnych na zapas, sędziowie nieorzekający, próba ustanowienia nowego modelu sądownictwa konstytucyjnego

\section{Regulating the election of judges of the Constitutional Tribunal in the Act of 25 June 2015 on the Constitutional Tribunal and its implications}

Wydawnictwo Sejmowe, Warszawa 2018, p. 179

The argument on the Constitutional Tribunal, which lasted from mid-2015 to the end of 2016, concerned three dimensions. First, it was about ascertaining the inadmissibility of electing judges in advance, as provided for by Article 137 of the Constitutional Tribunal Act of 25 June 2015; second, it was about pluralising the composition of the Constitutional Tribunal, and third - about an attempt at establishing a new model of the functioning of a constitutional court by the Law and Justice party. The third issue seemed the most important and is still the object of an ongoing systemic argument transgressing the events from the years 2015-2016, which has so far not been satisfactorily solved. The problem of electing judges was resolved by two rulings of the Constitutional Tribunal: judgment of 3 December 2015 (K 34/15) and the decision of 7 January 2016 (U 8/15). The effect of the Tribunal's decision was in fact giving the Sejm carte blanche as regards electing judges on 8 October 2015. 
KEY words: Constitutional Tribunal, electing constitutional judges in advance, non-adjudicating judges, an attempt at establishing a new model of constitutional court

Od konfliktu wokół wyboru sędziów Trybunału Konstytucyjnego w 2015 r. minęło niewiele czasu, a nauka prawa konstytucyjnego może już pochwalić się pierwszą monografią na ten temat, którą zawdzięczamy śp. prof. Bogusławowi Banaszakowi, jednemu z najwybitniejszych polskich konstytucjonalistów po 1989 r. Ta stosunkowo niewielka książka ukazała się po nagłej śmierci Autora, co sprawiło, że nie mógł On dokonać jej ostatecznej redakcji.

Całość składa się ze wspomnienia Julii Przyłębskiej, słowa wstępnego Bogumiła Szmulika, wprowadzenia oraz czterech rozdziałów. Pierwszy z nich dotyczy wyboru sędziów TK w dniu 8 października 2015 r., drugi poświęcony jest stanowisku zajętemu przez organy władzy publicznej wobec tego faktu, a ponadto wyborowi sędziów konstytucyjnych dokonanemu dnia 2 grudnia 2015 r. oraz analizie opinii Komisji Weneckiej, zaleceniom Komisji Europejskiej i rezolucji Parlamentu Europejskiego, trzeci odnosi się do skutków dyferencjacji przez Prezesa TK statusu sędziów wybranych przez Sejm w dniu 2 grudnia 2015 r. w okresie od 2 grudnia 2015 r. do 19 grudnia 2016 r.; wreszcie ostatni rozdział stanowi rodzaj podsumowania, w którym obowiązujące ustawy dotyczące Trybunału Konstytucyjnego rozpatrywane są z punktu widzenia ich znaczenia dla rozwiązania kontrowersji dotyczących wyboru sędziów TK oraz wyboru Prezesa TK, a także samego funkcjonowania tej instytucji.

Osią książki jest tytułowy wybór sędziów konstytucyjnych w 2015 r. i analizie poglądów Autora w tej kwestii będzie głównie poświęcona niniejsza recenzja. Implikacje natomiast tej sprawy, kompetentnie przedstawione przez śp. Profesora, będą miały mniejsze, niejako odpryskowe, znaczenie. Nieco uwagi chciałbym też poświęcić odpowiedzi na pytanie, dlaczego konflikt wokół Trybunału Konstytucyjnego przeciągnął się na prawie cały 2016 r., skoro problem wyboru sędziów został rozstrzygnięty w pierwszych dniach stycznia tamtego roku. Świętej pamięci Profesor, co prawda, nie zajmuje się tą sprawą, ale ma ona istotne znaczenie dla zrozumienia powodów przeciągania się konfliktu wokół TK w latach 2015-2016.

10 lipca 2013 r. prezydent Bronisław Komorowski wniósł do Sejmu projekt nowej ustawy o Trybunale Konstytucyjnym. 29 sierpnia 2013 r. miało miejsce pierwsze czytanie i projekt trafił do prac w komisjach; Komisje Sprawiedliwości i Praw Człowieka oraz Ustawodawcza powołały specjalną podkomisję do rozpatrzenia tego projektu. Wkrótce okazało się, że projekt ten został opracowany przez sędziów Trybunału Konstytucyjnego (s. 21-22), którzy niejako występowali we własnej sprawie. Następnie kilku sędziów konstytucyjnych na czele z prezesem Andrzejem Rzeplińskim intensywnie uczestniczyło w pracach legislacyjnych (s. 22). Później zresztą stało się to podstawą do wyłączenia ich z orzekania w przedmiotowej sprawie. 
W pracach Komisji Sprawiedliwości i Praw Człowieka dotyczących przedstawionego przez Prezydenta RP projektu ustawy o Trybunale Konstytucyjnym z 12 maja 2015 r. na wniosek posła Roberta Kropiwnickiego z Platformy Obywatelskiej dodano art. 136, umożliwiający jednorazowy wybór sędziów w miejsce tych, których kadencja upływa w 2015 r. W grę mógł wchodzić wybór nawet pięciu sędziów. Nie było takiej propozycji ani w przedłożeniu Prezydenta RP, ani nie uwzględniało jej Sprawozdanie Podkomisji. Byliby to sędziowie wybrani przez Sejm VII kadencji niejako na zapas. A rzecz dzieje się w sytuacji, gdy niespodziewanie nowym Prezydentem RP został Andrzej Duda, wygrywając z Bronisławem Komorowskim.

W trakcie posiedzenia Sejmu w dniu 26 maja 2015 r. poseł R. Kropiwnicki tłumaczył, dlaczego konieczny jest wybór tych dodatkowych sędziów. Miało to być spowodowane natłokiem spraw publicznych przy okazji rozpoczęcia prac Sejmu nowej kadencji. Z jego wypowiedzi wynikało, że kwestia niekonstytucyjności tego rodzaju rozwiązania prawnego nie była dla koalicji Platformy Obywatelskiej i Polskiego Stronnictwa Ludowego sprawą najważniejszą, skoro chodziło o to, aby nie doszło do powstania wakatów w obsadzie TK. Następnego dnia głosami rządzącej koalicji nowa ustawa o Trybunale Konstytucyjnym została uchwalona przez Sejm.

Przyjęcie nowej ustawy o Trybunale Konstytucyjnym nastąpiło ostatecznie 25 czerwca 2015 r. (Dz.U. poz. 1064). Przepis art. 137 (poprzednio był to dodany art. 136) dawał Sejmowi jednorazową możliwość wyboru pewnej liczby sędziów niejako na zapas. Można zapytać za Trybunałem Konstytucyjnym, który podnosił to w uzasadnieniu do wyroku z 3 grudnia 2015 r. (K 34/15), dlaczego ustawodawca ograniczył się jedynie do możliwości wyboru na zapas tych sędziów, których kadencja upływała w 2015 r., a nie w ogóle całego składu TK, skoro zerwano z zasadą, że wybór nowych sędziów przez Sejm był możliwy jedynie w sytuacji, gdy ich kadencja upływała w trakcie trwania kadencji Sejmu. Ta propozycja nie byłaby tak zupełnie kuriozalna, gdyż już Hans Kelsen proponował ,przyznanie samemu sądowi konstytucyjnemu prawa zgłaszania kandydatów na każde zwolnione miejsce albo jego obsadzenie w drodze wyboru (kooptacji)"'. Polski ustawodawca nie poszedł tak daleko, ale trudno odmówić mu pewnej oryginalności ustrojowej.

Wspominałem już, że w pracach nad nową ustawą o TK aktywnie uczestniczyli niektórzy sędziowie konstytucyjni z prezesem A. Rzeplińskim na czele. Nie wiemy nic o tym, aby w jakikolwiek sposób wyrażali oni wątpliwości co do konstytucyjności anonsowanego przepisu, raczej zgadzali się z przyjętym rozwiązaniem, o czym świadczyła chociażby wypowiedź Prezesa TK w trakcie prac legislacyjnych w Senacie (s. 28). Nie ma wątpliwości, że ich głos mógłby mieć znaczenie dla posłów koalicji PO-PSL przy stanowieniu przepisu art. 137, a przynajmniej byłby ważnym głosem sprzeciwu, którego zabrakło.

${ }^{1}$ H. Kelsen, Istota i rozwój sądownictwa konstytucyjnego, tłum. B. Banaszkiewicz, Warszawa 2009, s. 41. 
8 października 2015 r., tuż przed upływem VII kadencji Sejmu, dokonany został wybór pięciu sędziów konstytucyjnych, przy czym w tym momencie trudno było powiedzieć, ilu z nich będzie wybranych na zapas. Prezydent B. Komorowski zarządził wybory parlamentarne na 25 października 2015 r. Tym samym Sejm VII kadencji, dokonując wyborów sędziów TK, powinien mieć świadomość, że kadencje sędziów, których wybiera, wygasną już po wyborach, a być może nawet i po wygaśnięciu kadencji samego Sejmu VII kadencji. Dzień ten zależał od terminu, na jaki prezydent A. Duda wyznaczy pierwsze posiedzenie nowo wybranego Sejmu, skoro wygaśnięcie kadencji sędziów konstytucyjnych przypadało między 6 listopada a 9 grudnia 2015 r. Słowem, liczba sędziów wybranych nieprawidłowo zależała jedynie od decyzji głowy państwa, a gdyby pierwsze posiedzenie Sejmu VIII kadencji zostało zwołane przed 6 listopada, co jak najbardziej w świetle przepisu art. 109 ust. 2 Konstytucji RP było dopuszczalne, to wszyscy nowi sędziowie byliby wybrani wadliwie. Szkoda, że to zagadnienie umknęło Autorowi prezentowanej monografii.

Warto przypomnieć, że inaczej postąpił Sejm II kadencji, który postanowił nie obsadzać trzech nowych stanowisk sędziów (utworzonych po powiększeniu składu TK z 12 do 15 sędziów, o czym stanowiła nowa Konstytucja RP) i pozostawić to nowo wybranemu Sejmowi, mimo że formalnie jego kadencja kończyła się 20 października 1997 r., a więc na dzień przed pierwszym posiedzeniem nowo wybranego Sejmu. Trafnie przypomniał o tym fakcie śp. Profesor (s. 31).

O wyborze pięciu sędziów konstytucyjnych w dniu 8 października 2015 r. zadecydowały głosy koalicji PO-PSL, której sondaże pokazywały przegraną w bliskich już wyborach parlamentarnych, a jeszcze wcześniej obie te partie poniosły porażkę w wyborach prezydenckich. W głosowaniu wzięli udział posłowie Prawa i Sprawiedliwości, byli oni jednak przeciwko wyborowi wszystkich przedstawionych kandydatów na stanowiska sędziów TK. Na stanowiska sędziów konstytucyjnych wybrani zostali: Roman Hauser, Andrzej Jakubecki, Krzysztof Ślebzak oraz Bronisław Sitek i Andrzej Jan Sokala (M.P. poz. 1038-1042).

W trakcie październikowych wyborów na stanowisko sędziego konstytucyjnego obowiązywały dwie odmienne regulacje prawne: jedna zawarta w nowej ustawie o TK, druga wynikająca z regulaminu Sejmu z 30 lipca 1992 r. (M.P. 2012, poz. 32 z późn. zm.), czym szeroko zajmuje się Autor (s. 29, 32-33). Było to wyraźnie widoczne przy wskazaniu podmiotu mającego uprawnienie do zgłoszenia kandydatów na sędziów TK. Sejm zastosował tu nie rozwiązanie przewidziane w art. 19 ust. 1 ustawy o TK z 25 czerwca 2015 r., lecz unormowanie regulaminowe i w rezultacie kandydatów zgłosiło tylko Prezydium Sejmu. Jednak Sejm w odniesieniu do terminu złożenia wniosku i w sprawie zgłoszenia kandydata na sędziego TK oraz w sprawie samego wyboru sędziów odwołał się do regulacji ustawowej. Tym samym wybór tych kandydatów na stanowisko sędziego TK przez Sejm dnia 8 października 2015 r. był wadliwy od samego początku, skoro w nieuprawniony sposób połączono elementy dwóch trybów, zamiast zdecydować się na jeden z nich. Słowem, nie można w ramach 
jednego procesu wyborczego stosować norm pochodzących z dwóch aktów prawnych ze sobą niezharmonizowanych, czego trafnie dowiódł Autor.

Jerzy Zajadło sformułował następującą opinię, że „gdyby w Polsce któraś z dominujących sił politycznych zdobyła pełnię władzy, czego nie możemy wykluczyć, na osiem lub dwanaście lat, to jest w stanie tak skonstruować skład Trybunału, by uczynić z niego organ de facto politycznie podporządkowany partiom kontrolującym władzę ustawodawczą i wykonawczą"2. Wypadki z połowy 2015 r. istotnie zmodyfikowały ten pogląd. Otóż koalicja PO-PSL chciała skonstruować per fas et nefas taki skład TK, aby zabezpieczyć się na wypadek spodziewanej utraty władzy, a nie jako siła nadal dominująca politycznie. Rzeczywiście, są takie rzeczy na niebie i ziemi, o których się nie śniło filozofom. Szekspir wiedział o tym dużo wcześniej niż my. Myślę, że nic przeciwko tego rodzaju opiniom nie miałby śp. Profesor, aczkolwiek $\mathrm{w}$ recenzowanej pracy ten wątek nie został podniesiony.

Sejm dnia 25 listopada 2015 r. podjął pięć uchwał dotyczących stwierdzenia braku mocy prawnej uchwał Sejmu z dnia 8 października 2015 r. w sprawie wyboru sędziego Trybunału Konstytucyjnego opublikowanych w Monitorze Polskim z 25 października 2015 r., poz. 1038-1042 (M.P., poz. 1131-1135). Chodziło nie o uchylenie tych uchwał, ale właśnie o stwierdzenie braku mocy prawnej ze względu na nieprawidłowości związane z zastosowanym trybem wyborczym, a to nie to samo, o czym szeroko traktuje Autor (s. 50-57). Inicjatywa uchwałodawcza należała do Klubu Parlamentarnego PiS. Debata przebiegała bardzo burzliwie, co wynikało z protestów posłów PO i Nowoczesnej.

Każda z uchwał Sejmu z dnia 25 listopada 2015 r. miała ten sam lakoniczny kształt. Poza stwierdzeniem braku mocy prawnej dokonanego dnia 8 października 2015 r. wyboru na stanowisko sędziego konstytucyjnego określonej osoby zawierała prośbę do Prezydenta RP „o powstrzymanie się od odbioru ślubowania od osoby wskazanej w przedmiotowej uchwale". W żadnej z listopadowych uchwał Sejmu nie była podana przyczyna stwierdzenia braku mocy prawnej uchwał Sejmu z dnia 8 października 2015 r., jedynie poseł Stanisław Piotrowicz próbował ją sformułować w trakcie debaty sejmowej, powołując się na ekspertyzy prawne sejmowego Biura Studiów i Ekspertyz (obecnie Biuro Analiz Sejmowych). Autor co prawda pisze o tym, choć wyraźnie tego nie podkreśla (s. 50-51).

Prezydent A. Duda wstrzymał się z przyjęciem ślubowania od sędziów wybranych przez Sejm w dniu 8 października 2015 r. Działał tu w imię ochrony wartości konstytucyjnych, do czego jest zobowiązany jako organ czuwający nad przestrzeganiem konstytucji (art. 126 ust. 2 Konstytucji RP). Trafnie kwestię tę analizuje śp. Profesor (s. 35-46). Trybunał Konstytucyjny w uzasadnieniu wyroku z 3 grudnia 2015 r. słusznie „dostrzega, że w pewnych wyjątkowych okolicznościach mogą zaistnieć takie sytuacje, które w sposób obiektywny będą nakazywały Prezydentowi chronić wyższą wartość - niż

2 J. Zajadło, Wewnętrzna legitymizacja sądu konstytucyjnego, „Przegląd Sejmowy” 2009, nr 4(93), s. 130 . 
niezwłoczne wypełnienie obowiązku przyjęcia ślubowania — jaką stanowi nadrzędność Konstytucji”. Właśnie z taką sytuacją mieliśmy wówczas do czynienia. Jeśli weźmiemy pod uwagę jedynie wyrok TK z 3 grudnia 2015 r., to w przypadku dwóch sędziów Prezydent RP postąpił w zgodzie z zawartym tam stanowiskiem. Co do trzech pozostałych osób uzasadnieniem dla głowy państwa było unieważnienie w drodze uchwały przez Sejm VIII kadencji ich wyboru na stanowiska sędziów.

Takie zachowanie prezydenta A. Dudy otworzyło drogę do wejścia do Trybunału Konstytucyjnego trójce sędziów wybranych przez Sejm 2 grudnia 2015 r. Opozycja parlamentarna uznała to za niezgodne z prawem, uważając te miejsca za wcześniej obsadzone, zaś prezes A. Rzepliński nie wyraził zgody na podjęcie przez nich orzekania, co nie miało żadnych podstaw prawnych. Szerokiej analizie poddał tę sprawę śp. Profesor w rozdz. III swojej monografii. Na gruncie postanowienia TK z 7 stycznia 2016 r. (U 8/15) wolną rękę w sprawie obsady pięciu stanowisk sędziów konstytucyjnych posiadał Sejm, a tym samym Prezydent RP mógł się zachować zgodnie z jego decyzjami $\mathrm{z}$ listopada i grudnia $2015 \mathrm{r}$.

Kwestią legalności wyboru przez Sejm w dniu 8 października 2015 r. pięciu sędziów zajął się TK w wyroku z 3 grudnia 2015 r. Wspominałem już, że Trybunał Konstytucyjny uznał wtedy dwóch spośród nich za wybranych niezgodnie z prawem, gdyż Sejm może obsadzać stanowiska jedynie tych sędziów, których kadencja wygasa $\mathrm{w}$ trakcie kadencji parlamentu, niedopuszczalne zaś jest obsadzanie stanowisk sędziów niejako na zapas. Co do pozostałych sędziów orzeczono, że możliwość dokonania ich wyboru była zgodna z konstytucją, aczkolwiek TK nie zajął się oceną zgodności z prawem samych wyborów, bo to akty stosowania prawa, a nie stanowienia prawa, zatem na gruncie Konstytucji RP nie podlegają kognicji sądu konstytucyjnego. W analizowanym wyroku TK nie odniósł się do wyboru trzech sędziów dokonanego przez Sejm 2 grudnia 2015 r. Z niewiadomych powodów prezes Rady Ministrów Beata Szydło nie podjęła decyzji o publikacji tego wyroku w Dzienniku Ustaw, jednak Autor mógłby się nie zgodzić z tym poglądem.

Swoje stanowisko Trybunał Konstytucyjny potwierdził w postanowieniu z 7 stycznia 2016 r. w sprawie związanej z kontrolą uchwał Sejmu o wyborze Henryka Ciocha, Marka Muszyńskiego, Lecha Morawskiego, Julii Przyłębskiej i Piotra Pszczółkowskiego na stanowiska sędziów konstytucyjnych. Postępowanie uległo umorzeniu ze względu na niedopuszczalność wydania orzeczenia, gdyż mamy do czynienia z aktami stosowania, a nie stanowienia prawa.

Przedmiotem powyższego postanowienia TK było również rozpatrzenie zgodności z konstytucją uchwał Sejmu z 25 listopada 2015 r. w sprawie stwierdzenia braku mocy prawnej uchwał Sejmu z dnia 8 października 2015 r. w sprawie wyboru sędziego Trybunału Konstytucyjnego, o co wnosili wnioskodawcy. TK i w tym zakresie umorzył postępowanie, bo z art. 188 Konstytucji RP wynika, że badanie zgodności uchwał Sejmu z konstytucją nie podlega jego kognicji, gdy nie zawierają one norm prawnych. W wyroku z 19 czerwca 1992 r. (U 6/92) TK zajął się jednak badaniem konstytucyjności uchwały Sejmu z 28 maja 1992 r. w sprawie zobowiązania 
Ministerstwa Spraw Wewnętrznych do przedstawienia pełnej informacji na temat osób pełniących niektóre funkcje publiczne będących współpracownikami Służby Bezpieczeństwa w latach 1945-1990, bowiem dostrzegł w niej istnienie treści o charakterze normatywnym. Efektem postanowienia TK z 7 stycznia 2016 r. byłoby w gruncie rzeczy pozostawienie Sejmowi carte blanche w sprawie wyborów sędziów w dniu 8 października $2015 \mathrm{r}$.

Warto zaznaczyć, że w przypadku B. Sitka oraz A.J. Sokali stanowisko Sejmu i Trybunału Konstytucyjnego było takie samo: nie są oni sędziami konstytucyjnymi. Różnica dotyczyła trzech pozostałych osób (chodziło o R. Hausera, A. Jakubeckiego oraz K. Ślebzaka). Sprowadzała się ona do tego, że w opinii sądu konstytucyjnego wybór tych osób na stanowiska sędziowskie był w ogóle możliwy, co nie znaczy, że został dokonany zgodnie z prawem, natomiast Sejm uznał, że wybrano ich niezgodnie z prawem.

Trybunał Konstytucyjny na przełomie lat 2015 i 2016 wyraźnie sformułował intencję nieuczestniczenia w sporze, który coraz bardziej nabierał charakteru politycznego. Charakterystyczne też było to, że w sprawie postanowienia TK z 7 stycznia 2016 r. zdanie odrębne zgłosił prezes A. Rzepliński, co mogłoby świadczyć o chęci podtrzymania konfliktu wokół wyboru sędziów. Sądzę, że TK za swoje désintéressement w sprawie wyboru pięciu sędziów mógł oczekiwać, że PiS nie będzie próbowało ustanowić nowego modelu sądownictwa konstytucyjnego, a tak, jak wiadomo, się nie stało. Sędziowie konstytucyjni, wierząc $w$ siłę reprezentowanej przez siebie instytucji, uważali, że nie zagrożą jej wybory sędziów przez nową większość parlamentarną, bo z czasem przystosują się oni do obowiązującego w TK modelu funkcjonowania, natomiast rzeczywistym zagrożeniem mogłyby być zmiany dokonane w kształcie reżimu prawnego Trybunału Konstytucyjnego. Jest oczywiste, że takiego stanowiska nie podzielałaby grupa sędziów skupionych wokół ówczesnego Prezesa TK. Ich zdaniem nowi sędziowie będą rodzajem ciała obcego w łonie sądu konstytucyjnego, a ponadto zwolennicy prezesa A. Rzeplińskiego mogli zakładać, że zainteresowanie PiS Trybunałem Konstytucyjnym na tym się nie skończy, trzeba więc niejako od początku zajmować ofensywne stanowisko.

Recenzowana praca zawiera ponadto dwa obszerne rozdziały dotyczące skutków dyferencjacji przez Prezesa TK statusu sędziów wybranych przez Sejm 2 grudnia 2015 r. (rozdz. III) oraz sposobu likwidacji tego stanu rzeczy, a także wyboru nowego Prezesa TK (rozdz. IV). Z punktu widzenia tytułowego problemu prezentowanej książki nie są to sprawy o kluczowym znaczeniu, aczkolwiek dobrze, że zostały kompetentnie wyjaśnione. Znacznie ciekawsza byłaby analiza dalszych działań legislacyjnych partii Jarosława Kaczyńskiego, czego już nie czyni śp. Profesor. Nie należy tego traktować jako zarzutu, chodziłoby raczej o pokazanie rzeczywistych przyczyn tak długotrwałegp konfliktu wokół wyboru sędziów konstytucyjnych w 2015 r.

Punkt wyjścia dla działań legislacyjnych PiS stanowił program tej partii „Nowoczesna, solidarna, bezpieczna Polska" z 2009 r. ${ }^{3}$ Stwierdza się tam, że Trybunał

\footnotetext{
${ }^{3}$ Nowoczesna, solidarna, bezpieczna Polska. Program Prawa i Sprawiedliwości, Kraków 2009, druk powielony.
} 
Konstytucyjny posiada możliwość „w praktyce dowolnego blokowania władzy ustawodawczej i wykonawczej oraz «kreatywnego» definiowania zakresu swoich uprawnień"”. Wkrótce dowiedzieliśmy się, jaki sens prawnokonstytucyjny mogły mieć tego rodzaju tezy polityczno-ustrojowe. W $2010 \mathrm{r}$. powstał drugi projekt konstytucji autorstwa PiS 5 . $\mathrm{W}$ art. 135 wprowadzono generalną zasadę orzekania w sprawach z zakresu kontroli konstytucyjności prawa kwalifikowaną większością 12 sędziów, przy czym pełny skład to 15 sędziów na wszystkich 18 . W razie braku wymaganej większości postępowanie miałoby ulegać umorzeniu. W praktyce stwierdzenie niekonstytucyjności jakiegoś aktu prawnego byłoby osiągalne, lecz bardzo trudne ${ }^{6}$. Innymi słowy, tego rodzaju orzeczenie Trybunału Konstytucyjnego odnosiłoby się jedynie do przypadków bezdyskusyjnego naruszenia ustawy zasadniczej.

Zatem partii J. Kaczyńskiego przed objęciem władzy w 2015 r. nie chodziło o powrót do modelu TK jako organu quasi-sądowokonstytucyjnego, z jakim mieliśmy do czynienia do 1997 r., ani tym bardziej o powtórzenie modelu, jaki dominował po wejściu w życie Konstytucji RP. Stąd nie było mowy o odebraniu orzeczeniom TK charakteru ostatecznego, ale szło o ograniczenia sędziowskiego aktywizmu. Z pewnością nie chciano w ten sposób dopuścić do okrzepnięcia w Polsce rządu sędziów, szukając w to miejsce nowego aequilibrium między zasadą suwerenności narodu, ideą demokracji politycznej a instytucją sądowego badania konstytucyjności prawa ${ }^{7}$. Szkoda, że w ogóle nie dostrzegł tego problemu Autor, bo bez uwzględnienia tej kwestii przeciągający się w 2016 r. konflikt wokół TK staje się całkowicie niezrozumiały.

Dokonajmy choćby pobieżnej analizy aktów ustawowych z lat 2015-2016, aby się przekonać, jak PiS poradziło sobie ze stworzeniem nowego modelu Trybunału Konstytucyjnego ${ }^{8}$. Chodzi o ustawę z 19 listopada 2015 r. o zmianie ustawy o TK (Dz.U. poz. 1928 i 2147), ustawę z 22 grudnia 2015 r. o zmianie ustawy o TK (Dz.U. poz. 2217), ustawę o TK z 22 lipca 2016 r. (Dz.U. poz. 1157) oraz trzy ustawy: z 30 listopada 2016 r. o organizacji i trybie postępowania przed Trybunałem Konstytucyjnym (Dz.U. poz. 2072), z 30 listopada 2016 r. o statusie sędziów Trybunału Konstytucyjnego (Dz.U. poz. 2073) oraz z 13 grudnia 2016 r. — Przepisy wprowadzające ustawę o organizacji i trybie postępowania przed Trybunałem Konstytucyjnym oraz ustawę o statusie sędziów Trybunału Konstytucyjnego (Dz.U. poz. 2074). Konstytucyjność trzech pierwszych aktów prawnych badał TK, wypowiadając się na ich temat bardzo krytycznie, obficie wskazując na niekonstytucyjność zawartych tam

${ }^{4}$ Ibidem, s. 41.

${ }^{5}$ Projekt konstytucji PiS, Warszawa 2010, druk powielony. Szerzej vide L. Mażewski, Instytucja Prezydenta RP wedtug Jarosława Kaczyńskiego i w projektach konstytucji Prawa i Sprawiedliwości, „Przegląd Sejmowy” 2016, nr 4(135), s. 33-41.

${ }^{6}$ Inną ocenę tego rozwiązania prawnego sformułował A. Sulikowski, Trybunał Konstytucyjny a polityczność. O konsekwencjach upadku pewnego mitu, „Państwo i Prawo” 2016, nr 4, s. 9.

7 Vide L. Mażewski, Wiele hałasu o nic? Konflikt wokót Trybunału Konstytucyjnego w latach 2015-2016 w perspektywie rozważań modelowych, Warszawa-Radzymin 2017, rozdz. IX.

${ }^{8}$ Szerzej ibidem, rozdz. VIII. 
rozwiązań prawnych. Chodzi o wyroki z 9 grudnia 2015 r. (K 35/15), 8 marca 2016 r. (K 47/15) i 11 sierpnia 2016 r. (K 39/16).

Pierwsza nowela z 19 listopada 2015 r. ustawy o TK z 25 czerwca 2015 r., dotycząca trybu wyboru Prezesa Trybunału Konstytucyjnego oraz złożenia ślubowania przez sędziego, nie miała większego wpływu na model TK, jednak znacznie ograniczała dominację prezesa nad sądem konstytucyjnym.

Nieco inaczej sprawy miały się z nowelą z 22 grudnia 2015 r. obowiązującej wówczas ustawy o TK. Ponownie zmieniony zostaje tryb wyboru Prezesa Trybunału Konstytucyjnego, wprowadzono „w szczególnie rażących przypadkach” możliwość zwrócenia się przez Zgromadzenie Ogólne Trybunału do Sejmu z wnioskiem o złożenie z urzędu sędziego TK, na nowo określono wielkość i właściwość składów orzekających, ustanowiono zasadę, że wnioski są „,rozpatrywane według kolejności wpływu spraw do TK” i wreszcie, że „orzeczenia TK wydawane w pełnym składzie zapadają większością 2/3 głosów".

Docenić należy, że w drugiej noweli próbowano doprowadzić do sytuacji, w której stwierdzenie niekonstytucyjności ustaw zostałoby znacznie utrudnione, odnoszone jedynie do przypadków bezdyskusyjnych. Z pewnością mogłoby to stanowić wartościowy element nowego modelu Trybunału Konstytucyjnego. Nie ulega też wątpliwości, że istnieje tu nawiązanie do projektu konstytucji PiS z 2010 r.

Jeśli chodzi o ustawę z 22 lipca 2016 r. o TK, to w ważnych dla modelu Trybunału Konstytucyjnego sprawach powraca się właściwie do rozwiązań z noweli z 22 grudnia 2015 r. Jednak zgodnie z treścią przepisu art. 69 ust. 1 orzeczenia miały zapadać zwykłą większością głosów, a nie jak proponowano uprzednio - większością $2 / 3 \mathrm{w}$ przypadku orzeczeń wydawanych $\mathrm{w}$ pełnym składzie. Poza tym $\mathrm{z}$ art. 68 ust. 5 wynikało, że w trakcie narady w pełnym składzie co najmniej czterech sędziów może zgłosić sprzeciw wobec proponowanego rozstrzygnięcia, jeśli uzna, że rozpatrywane zagadnienie ma szczególnie doniosły charakter ze względów ustrojowych lub ze względu na porządek publiczny i nie zgodzi się z kierunkiem rozstrzygnięcia. W przypadku złożenia sprzeciwu, o którym mowa w tym ustępie, narada ulega odroczeniu o 3 miesiące, a sędziowie, którzy złożyli sprzeciw, na kolejnej naradzie zwołanej po upływie tego terminu prezentują wspólną propozycję rozstrzygnięcia. Jeżeli w trakcie ponownej narady, o której mowa w ust. 6, ponownie co najmniej czterech sędziów zgłosi sprzeciw, narada ulega odroczeniu o kolejne 3 miesiące. Po upływie tego terminu przeprowadza się następną naradę i głosowanie.

W lipcowej ustawie o TK wyrażono stanowisko, że problemy związane z rolą ustrojową Trybunału Konstytucyjnego nie zostaną rozwiązane tylko poprzez doprowadzenie do większego spluralizowania składu, ale potrzebna byłaby próba prawnego ograniczenia jego działalności jako „pozytywnego ustawodawcy”. Nie kadry przecież decydują o wszystkim, istnieje również konieczność ukształtowania odpowiednich rozwiązań instytucjonalnych.

I wreszcie ustawy z końca 2016 r., które zostały ustanowione w sytuacji, gdy wybrani przez PiS sędziowie będą stanowili większość TK. W tym przypadku partia 
J. Kaczyńskiego mogłaby sobie pozwolić na sformułowanie nowego modelu sądu konstytucyjnego, gdyż niechętni jej sędziowie stanowiliby już mniejszość. Problemem nie powinny być również poglądy wyrażane w poprzednich wyrokach TK w sprawie konstytucyjności rozwiązań prawnych proponowanych przez PiS, bowiem sąd konstytucyjny może, orzekając w pełnym składzie, zmienić stanowisko w tych samych czy podobnych sprawach, a pewne rozchwianie orzecznictwa jest codzienną praktyką wszystkich sądów.

Niespodzianka polegałaby na tym, że uchwalone pod koniec 2016 r. trzy ustawy nie wprowadzają żadnych zmian w stosunku do modelu TK, z jakim mieliśmy do czynienia na gruncie stanu prawnego z 25 czerwca 2015 r. Oznaczałoby to, że PiS całkowicie rezygnuje ze swojego programu z 2009 r. i projektu konstytucji z następnego roku, uważając, że osiągnięcie większości przez wybranych przezeń sędziów rozwiązuje problem. Byłby to odwrót od poglądu przyjętego w ustawie o TK z 22 lipca 2016 r. Innymi słowy, partia J. Kaczyńskiego podporządkowałaby się de facto krytycznym wyrokom TK w sprawie postulowanego przez siebie modelu sądu konstytucyjnego.

Zdaniem Adama Sulikowskiego ,prawdopodobnie sądy konstytucyjne w ich dotychczasowej postaci zostaną wyeliminowane. Jeżeli się ostaną [...], to będą musiały się włączyć do walki o aprobatę mas [...]. Jeżeli TK przetrwa albo jeżeli zostanie odbudowany w postaci innej niż szczątkowa, to jego argumentacja będzie musiała być pragmatyczna. Niezbędna tym samym stanie się zmiana stylu orzekania, umożliwiająca sądowi konstytucyjnemu pozyskanie aprobaty mas" " Z perspektywy kilku lat można stwierdzić, że tego rodzaju opinie nie mają żadnej podstawy, aczkolwiek nie da się przesądzić, jaka będzie przyszłość Trybunału Konstytucyjnego w Polsce.

Zatem efekt konfliktu wokół Trybunału Konstytucyjnego, z jakim mieliśmy do czynienia w latach 2015-2016, ma dość nieprzewidziany charakter. Jedynym jego namacalnym rezultatem jest początkowo spluralizowanie składu TK, a obecnie osiągnięcie zdecydowanej większości przez sędziów wybranych przez PiS, bez jakiejkolwiek zmiany modelu funkcjonowania tego organu. Partia J. Kaczyńskiego w przyjętym ostatecznie ustawodawstwie nie przedstawiła żadnej propozycji rozwiązania konfliktu między zasadą zwierzchnictwa narodu, ideą demokratyczną a konsekwencjami badania konstytucyjności prawa przez sąd konstytucyjny. Było oczywiste, że nie wchodzi w grę powrót do modelu TK, w ramach którego orzeczenia o niekonstytucyjności ustawy nie miały charakteru ostatecznego. Tej opcji ustrojowej w PiS w ogóle nie brano pod uwagę. Ale między utrzymaniem status quo a powrotem do ustrojowej przeszłości z lat 1982/1985-1997 jest przecież cała gama możliwości, które proponował PiS, będąc w opozycji. Czyżby po raz kolejny miało się okazać, że punkt widzenia zależy od punktu siedzenia? W sumie nie byłoby to nic aż tak zaskakującego, takie rzeczy w polityce często się zdarzają.

Celem nowego aequilibrium ustrojowego byłoby minimalizowanie możliwych sytuacji konfliktowych między zasadą zwierzchnictwa narodu, ideą demokratyczną

9 J. Karczewski, Trybunat Konstytucyjny - teraźniejszość i przyszłość, „Państwo i Prawo” 2016, nr 8, s. 105. 
a konsekwencjami badania konstytucyjności prawa przez sąd konstytucyjny; w tym miejscu podkreślam słowo „minimalizowanie”, gdyż jakieś radykalne rozwiązanie jest tu niemożliwe. PiS — mimo szumnych zapowiedzi — niczego w tej sprawie nie uczynił.

Konflikt wokół Trybunału Konstytucyjnego, jaki rozpoczął się w Polsce wraz z uchwaleniem ustawy z 2015 r. o TK, zawierającej niekonstytucyjny przepis umożliwiający wybór sędziów na zapas, zakończył się na razie przyjęciem trzech ustaw o TK z 30 listopada i 13 grudnia 2016 r., likwidacją instytucji sędziów nieorzekających, które to pozaprawne novum wprowadził pod koniec 2015 r. prezes A. Rzepliński, oraz powołaniem 21 grudnia 2016 r. przez prezydenta A. Dudę J. Przyłębskiej na stanowisko prezesa Trybunału Konstytucyjnego, o czym traktuje rozdz. IV 2b omawianej monografii. Piszę „na razie”, bowiem nie wiadomo, co przyniesie przyszłość. Przejawem tej niepewności są choćby stale powtarzane tezy Platformy Obywatelskiej czy lewicy o „sędziach dublerach" i zapowiedzi generalnych zmian w ustroju i funkcjonowaniu TK.

Trwający półtora roku spór rozgrywał się na trzech płaszczyznach. Po pierwsze, chodziło o stwierdzenie niemożności wyboru sędziów na zapas, co ustanowił art. 137 ustawy o TK z 2015 r., po wtóre - o spluralizowanie składu TK i wreszcie po trzecie - o próbę wypracowania przez partię J. Kaczyńskiego nowego modelu funkcjonowania Trybunału Konstytucyjnego. Najważniejsza wydawała się ta trzecia sprawa, pozostająca ciągle przedmiotem ustrojowych kontrowersji znacznie wykraczających poza wydarzenia z lat 2015-2016, nieznajdująca jednak, jak dotychczas, zadowalającego rozwiązania.

Recenzowana monografia świetnie analizuje tytułowy problem wyboru sędziów TK w 2015 r., ale śp. Profesorowi jakby umyka, że z punktu widzenia PiS miał on charakter incydentalny. Nie szło też tylko o spluralizowanie obsady Trybunału Konstytucyjnego. Chodziło o coś znacznie istotniejszego, a mianowicie o ustanowienie nowego modelu sądownictwa konstytucyjnego w Polsce, stawiającego tamę nadmiernemu aktywizmowi sędziowskiemu. To z kolei zakończyło się zupełnym niepowodzeniem. Tu zwycięstwo odnieśli sędziowie, których nie ma już w składzie TK. Ich przekonanie co do właściwości obecnego modelu sądownictwa konstytucyjnego okazało się silniejsze niż polityczno-ustrojowa wola zmiany tego stanu rzeczy artykułowana przez partię J. Kaczyńskiego. Trzeba powiedzieć, że stało się to ze szkodą dla ustroju Polski, bo w ten sposób straciliśmy możliwość ułożenia na nowo stosunków między zasadą zwierzchnictwa narodu, ideą demokratyczną a instytucją sądowego badania konstytucyjności prawa.

Lech Mażewski*

* Dr hab. Lech Mażewski, ustrojoznawca, doradcy@wp.pl, https://orcid.org/0000-0002-0662-2260 